\title{
Wawasan Kebersihan Lingkungan \& Keberagamaan; Praktik Kebersihan Lingkungan pada Civitas Akademika UIN Imam Bonjol Padang
}

Indonesian Journal of Religion and Society, 2019, Vol. 01 (01), 80-92

(C) The Journal, 2019

www.journal.lasigo.org/index.php/IJRS

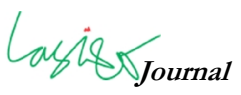

Article History

Received : March, $1^{\text {st }} 2019$

Revised: June, 29nd 2019

Accepted : June, 30 2019

\section{Rulan Permata Sari}

SDIT Insan Kamil, Padang Gading, Bengkulu, Indonesia

rulanpermatasari@gmail.com

\begin{abstract}
The basic identity of academic community of UIN Imam Bonjol Padang is Muslim, with sufficient religious knowledge. This study aims to see the correlation of knowledge with behavior in maintaining environmental cleanliness. The research data collection was carried out by survey and in-depth interviews with the academic community of UIN Imam Bonjol. This study found that, first the understanding of the academic community of UIN Imam Bonjol Padang about cleanliness was quite good at the individual level originating from the hadith about cleanliness, both in text and in substance. Second, in maintaining cleanliness, UIN academics are influenced by the lack of available hygiene facilities and infrastructure and the absence of regulation. Third, there is an asymmetrical relationship between the knowledge of the UIN academic community about environmental hygiene and practice because the understanding of environmental hygiene is still in the domestic area and is private in nature, not yet entering the public space.
\end{abstract}

Keywords: environmental hygiene; environmental cleanliness insight; environmental cleanliness practice

\begin{abstract}
ABSTRAK
Basis identitas yang dimiliki sivitas akademika UIN Imam Bonjol Padang adalah muslim, dengan pengetahuan keagamaan yang cukup memadai. Penelitian ini bertujuan untuk melihat korelasi pengetahuan tersebut dengan perilaku dalam menjaga kebersihan lingkungan. Pengumpulan data penelitian dilakukan dengan metode survey dan wawancara mendalam terhadap civitas akademika UIN Imam Bonjol. Studi ini menemukan bahwa pertama, pemahaman civitas akademika UIN Imam Bonjol Padang tentang kebersihan cukup baik pada level individu yang bersumber pada hadis tentang kebersihan, baik secara teks maupun secara substansi. Kedua, dalam menjaga kebersihan, civitas akademika UIN dipengaruhi oleh kurangnya sarana dan prasarana kebersihan yang tersedia dan ketiadaan regulasi. Ketiga, terdapat hubungan asimetris antara pengetahuan civitas akademika UIN tentang kebersihan lingkungan dengan pengamalan karena pemahaman mengenai kebersihan lingkungan masih di area domestik dan bersifat privat, belum masuk ke ruang publik.
\end{abstract}

Kata Kunci: kebersihan lingkungan; wawasan kebersihan lingkungan; praktek kebersihan lingkungan

Corresponding Author:

Name : Rulan Permata Sari

Email : rulanpermatasari@gmail.com 


\section{Pendahuluan}

Topik kebersihan dalam kajian keislaman merupakan pembahasan yang fundamental. Islam sangat memprioritaskan kebersihan dalam setiap aspek kehidupan pemeluknya, termasuk kebersihan lingkungan. Salah satu contoh penting aspek kebersihan dalam Islam adalah perintah untuk berwudu sebelum melakukan ibadah shalat. Allah SWT menerangkan hal ini dalam surah al-Ma idah: 6

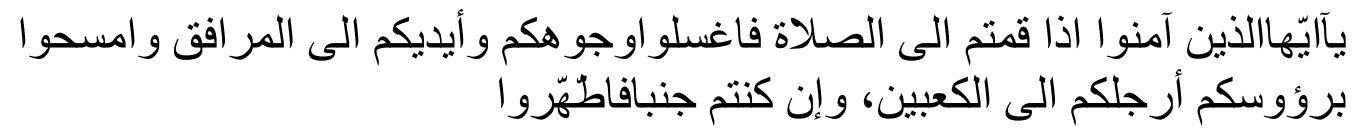

"Hai orang-orang yang beriman, apabila kamu hendak mengerjakan shalat, maka basuhlah mukamu dan tanganmu sampai dengan siku, dan sapulah kepalamu dan (basuh) kakimu sampai dengan kedua mata kaki, dan jika kamu junub maka mandilah..." (Q.S. al-Ma idah: 6).

Dalam kajian fikih, thaharah (kebersihan) merupakan topik yang dibahas diawal kitab sebelum topik ibadah lain seperti shalat, zakat, puasa dan lain lain. Hal tersebut dibahas dalam kitab al-Mughni, Fiqh Al-Sunnah, dan al-Umm. Tidak hanya dalam kajian fikih, kitab-kitab hadis induk seperti Sunan Abu Daud, Sunan al-Tirmidzi, dan Sunan al-Nasa juga membahas topik kebersihan diawal kitab, sedangkan Shahị Muslim membahas topik kebersihan setelah bab iman yang merupakan syarat pertama seseorang diakui sebagai muslim.

Dalam Islam, ada tiga istilah kebersihan yaitu thaharah, nazhafah dan tazkiyyah. Islam mengajarkan untuk senantiasa bersih dalam banyak hal, baik kebersihan diri maupun kebersihan lingkungan, kebersihan jasmani maupun rohani. Keduanya saling berhubungan dan tidak dapat dipisahkan. Istilah thaharah bermakna kebersihan jasmani dan rohani yaitu kebersihan hati, bersih dari usaha yang batil, kemunafikan dan kekafiran. Istilah nazhafah mengarah pada kebersihan secara fisik seperti pembahasan air, wudu, mandi, tayamum dan lain-lain. Hal tersebut merupakan cara-cara dalam membersihkan jasmani yang kemudian pada akhirnya melahirkan kebersihan rohani. Istilah kebersihan lainnya ialah tazkiyyah yang berkaitan dengan kebersihan harta dan jiwa. Dalam hal ini, penelitian dibatasi dalam istilah nazhafah dan thaharah dengan makna kebersihan fisik dalam konteks kebersihan lingkungan. Demikian juga dengan pesan Rasulullah bahwa senantiasa mengajarkan kepada umatnya untuk membiasakan hidup bersih karena Allah SWT menyukai kebersihan dan keindahan. Perintah membersihkan pekarangan dalam hadis di atas merupakan salah satu cara agar lingkungan tetap bersih dan indah.

Namun saat ini, kebersihan tidak lagi dianggap sebagai suatu keharusan bagi masyarakat muslim. Salah satu studi yang menjelaskan bahwa masyarakat muslim di Negara Islam seperti Nigeria, Maroko dianggap tidak ramah dalam persoalan lingkungan (Efendy, 2018). Hal ini tentu saja menjadi perhatian khusus. Sebagai masyarakat muslim, mestinya kebersihan merupakan pondasi awal keberagamaan. Namun sebaliknya, beberapa Negara yang dikenal mayoritas muslim justru tidak ramah lingkungan. Indonesia adalah salah satu negara dengan posisi 28 dari 108 negara di dunia yang tidak ramah lingkungan (Efendy, 2018). Salah satu sasaran utama untuk menguji tingkat pemahaman tentang kebersihan adalah lingkungan Universitas, terutama Universitas yang berbasis keislaman. Sebagai ruang terpelajar dan memiliki modal pemahaman keagamaan, lingkungan Universitas tentunya mencerminkan kepribadian yang bersih. Namun kenyataanya, pemahaman demikian tidak berbanding lurus dengan pemahaman tersebut.

Pada dasarnya, UIN Imam Bonjol Padang sudah mencoba untuk mengatasi persoalan tersebut melalui sosialiasi papan slogan tentang kebersihan. Tujuannya agar mahasiswa dan seluruh civitas akademika UIN Imam Bonjol Padang dapat mematuhi serta menyadari pentingnya kebersihan. Slogan tersebut dibingkai dan dipasang dipapan pengumuman agar tidak membuang sampah sembarangan serta di tempatkan dibeberapa titik yang potensial mencemari kebersihannya. Tempat potensial tersebut antara lain adalah dinding fakultas di sekitar tempat "kumpul" mahasiswa, atau di pinggir jalan kampus dan kamar mandi dengan slogan "Membuang sampah pada tempatnya adalah ibadah". Slogan yang sama 
dengan redaksi yang berbeda terdapat di pinggir jalan utama kampus, "Kami yakin Anda dapat membantu kami menjaga kebersihan Fakultas Tarbiyah dan Keguruan."

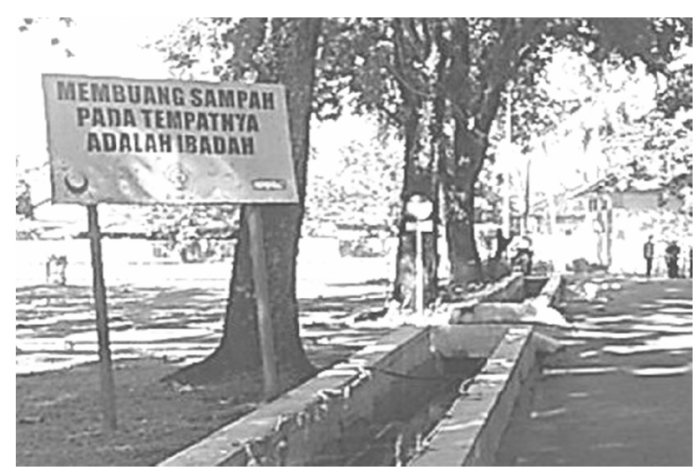

Gambar 1.

Slogan Kebersihan di Jalan Utama Kampus

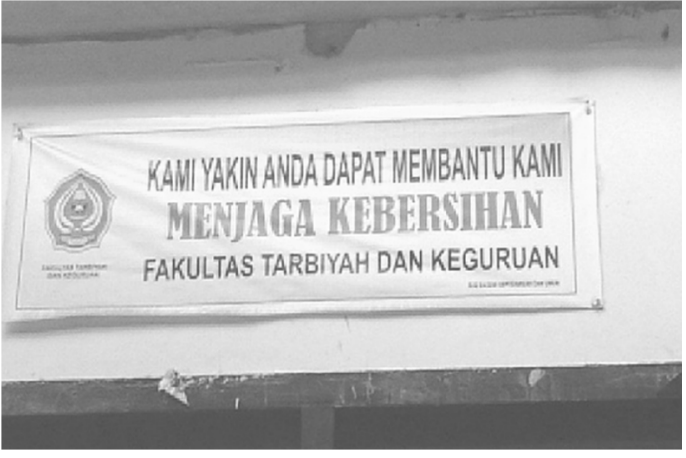

Gambar 2.

Slogan Kebersihan di Fakultas Tarbiyah

Dalam aktivitas keseharian civitas akademika UIN Imam Bonjol Padang, terjadi interaksi dengan slogan-slogan tersebut yang juga bertindak sebagai pengingat untuk selalu menjaga kebersihan lingkungan kampus. Selain wawasan keislaman civitas akademika UIN Imam Bonjol Padang yang juga mumpuni sebagaimana yang telah dipaparkan sebelumnya. Berangkat dari latar belakang di atas, penulis meneliti pengamalan hadis tentang kebersihan lingkungan dikalangan civitas akademika UIN Imam Bonjol Padang. Penelitian ini berdasarkan model kajian living hadis atau praktik di masyarakat yang diilhami oleh hadis. Lebih luas, Nurun Najwah menyatakan bahwa living hadis adalah aktivitas yang dikaitkan sebagai aplikasi dari meneladani Rasul atau dari teks-teks hadis (sumber-sumber yang jelas) atau yang diyakini ada. Dengan kata lain, living hadis adalah sebuah model kajian terhadap praktik atau prilaku masyarakat yang memiliki hubungan dengan hadis Nabi. Kajian ini diketahui sejauh mana pengamalan masayarakat terhadap hadis-hadis Nabi SAW.

\section{Kerangka Teori}

Konsepsi keberagamaan dapat diterjemahkan ke dalam serangkaian aktivitas, dedikasi, dan doktrin keagamaan. Istilah Durkheim dalam (Ritzer \& Goodman, 2010), terdapat segi sakral dan profan dalam sistem keberagamaan. Pada kenyataan sosial istilah "yang sakral" dan "yang profan" berjalin kelindan bersamaan dengan dinamika kehidupan masyarakat. Untuk memahami suatu ajaran, berbagai bentuk praktik keagamaan diterjemahkan melalui simbol yang dapat diterima secara sosial dan kultural. Praktik keberagamaan cenderung merupakan hasil dari serangkaian tafsiran oleh pemeluknya, bagaimana memaknai agama yang dianut, dan menginterpretasikan dalam kehidupan sehari-hari.

Dengan demikian, agama merupakan kelindan antara keyakinan murni dan kultural dalam konteks agama berkembang. Kontekstualisasi menjadi ciri khusus dari agama. Agama bersifat adaptif terhadap lingkungan sosial dan budaya karena agama merespon lingkungan kebudayaan (Abdullah, 2006) dan juga mendorong karifan lokal dalam menjaga leingkungan (Firdaus, 2012). Respon tersebut memungkinkan agama meninggalkan jejak religius dalam sesuatu yang secara simbolis diyakini mengandung nilai religius (Syahputra, 2016). Kendati agama merupakan persoalan makna (Kahmad, 2009), tetapi secara praksis terdapat perbedaan siginifikan kehidupan beragama dikalangan masyarakat primitif dan masyarakat modern (Azwar \& Muliono, 2019). Bagi masyarakat modern, kehidupan beragama hanya salah satu aspek atau merupakan bagian kecil dari kehidupan sehari-hari. Lingkungan seringkali terpinggirkan dalam kehidupan. Sehingga, masyarakat tidak sedikit juga mengenepikan persoalan lingkungan dalam praktik kehidupan.

Meskipun lingkungan juga bagian dari konsepsi nilai keberagamaan, namun pada praksisnya lingkungan hanya sesuatu yang dianggap ruang kosong yang tidak perlu diperhartikan. Tidak mengherankan dalam buku American Theocracy Kevin Phillips (2006) 
menjelaskan bahwa Amerika tidak dalam posisi on the track. Krisis lingkungan yang terjadi merupakan dampak serta pengaruh buruk dari kapitalisasi yang merambah dari berbagai aspek. Lingkungan diisi oleh sistem kapitalis untuk menumbuhkan kembangkan ketidak pedulian manusia terhadap lingkungan. Hal tersebut terlihat sebagai kesulitan untuk diperbaiki dan terus menerus akan mengganggu sektor ekologi (Maliki, 2011). Sama halnya yang dijelaskan oleh Kevin Phillips, Janet. K. Swim juga menjelaskan bahwa kelompok yang memiliki sumber daya sosial dan ekonomi yang sedikit cenderung paling rentan dengan kecacatan fisik dan jiwa serta hubungan dan proses antar kelompok. Sehingga, hal ini tidak berdampak baik terhadap tanggung jawab yang dimiliki untuk meningkatkan kepedulian terhadap lingkungan (Arditi, 2004; Swim et al., 2011).

Mestinya orang-orang muda mampu untuk mengatasi persoalan yang sedang dihadapi manusia dan mengarahakannya untuk kepentingan bersama. Seperti yang dijelaskan dalam penelitian Nora \& Minarti (2016) bahwa fungsi kognitif terjadi pada masa remaja, sehingga kaum muda mencari peluang dengan bantuk makna dan ketertiban. Pemaknaan yang dimaksud adalah bagian kotemplasi keagamaan yang menjadi basis ideologi, untuk melakukan sesuatu yang dianggap bermanfaat bagi orang lain. Salah satu bentuk azas manfaat tersebut adalah melalui kepeduliannya terhadap lingkungan. Gerakan yang dapat dilakukan salah satunya adalah melalui penumbuhkembangan etika lingkungan dan juga bagian dari cara agama dalam mentranformasikannya. Jika digunakan pendekatan konstruksionis, agama dengan nilai-nilai yang ditawarkan tentang lingkungan diinternalisasi oleh individu sebagai agen sehingga membentuk realitas subyektif. Nilai-nilai subyektif menjadi inti dari self-concept atau schemata menurut istilah kalangan fenomenologis. Self-concept dijadikan sebagai modal untuk mengkonstruksi, merespon dan membentuk realitas objektif yang berada di luar dirinya, termasuk mengkonstruksi, merespon dan membentuk alam lingkungan tempat tinggal (Maliki, 2011).

Dari sisi keagamaan dapat diamati relasi dengan kehidupan manusia (Farmer, Trapnell, \& Meston, 2009). Lima aspek agama dalam diri manusia dapat dijadikan sebagai basis ragam studi (dalam Ancok dan Suroro, 1995). Aspek tersebut antara lain yaitu dimensi keyakinan atau ideologis, peribadatan dan praktek keagamaan, dimensi penghayatan, dimensi pengamalan dan dimensi pengetahuan agama. Aspek ideologis berkaitan dengan seperangkat kepercayaan keagamaan yang memberikan penjelasan tentang Tuhan, alam manusia dan relasinya (Agus, 2006). Kepercayaan dapat berupa makna dari tujuan atau pengetahuan tentang perilaku baik yang dikehendaki Tuhan. Terdapat pengakuan akan kebenaran doktrin-doktrin dari agama yang dipatrikan semacam dogma. Aspek intelektual mengacu pada pengetahuan mengenai ajaran agama, seberapa jauh tingkat pengetahuan agama dan bagaimana individu memahami agama yang dianut. Serangkaian pengetahuan tersebut dapat bermuara pada dasar-dasar keyakinan, ritus-ritus kitab suci dan tradisitradisi. Aspek pengalaman merupakan bagian keagamaan yang bersifat efektif; keterlibatan emosional dan sentimental pada pelaksanaan ajaran. Individu maupun kelompok keagamaan merasakan persepsi dan sensasi dalam bentuk ritual.

Studi ini fokus pada praktik keberagamaan sebagai salah satu aspek dari studi agama yang menjadi pijakan analisa. Melalui pendekatan kerangka teoritik sebagaimana diulas, tulisan ini mengurai secara deskriptif analitis tentang bagaimana masyarakat kampus memahami konsepsi keagamaan, dalam hal ini hadis berkaitan dengan kebersihan, dan bagaimana mereka mempraktikkan konsepsi tersebut dalam lingkup sehari-hari. Praktik keberagamaan memungkinkan seseorang terlepas dari jejak religius dari agama itu sendiri. "Langit-langit yang suci" berlawanan makna dalam realitas kehidupan manusia dengan kultur dan perilaku sosial masyarakat.

\section{Metode Penelitian}

Penelitian pengamalan hadis tentang kebersihan lingkungan merupakan penelitian lapangan (field research), peneliti turun langsung ke lokasi penelitian dan berinteraksi langsung dengan objek penelitian. Penelitian dilakukan kurang lebih selama empat bulan sejak penelitian pertama dilakukan pada bulan April 2017 hingga Agustus 2017 di UIN 
Imam Bonjol Padang. Objek penelitian ini adalah civitas akademika UIN Imam Bonjol Padang, yaitu dosen dan mahasiswa. Hal ini berdasarkan ketetapan dalam UU No. 12 Tahun 2012 tentang Pendidikan Tinggi pada pasal 1 dan PP No. 30 Tahun 1990 tentang Pendidikan Tinggi pasal 1, bahwa civitas akademika adalah masyarakat akademik yang terdiri atas dosen dan mahasiswa. Dalam pengumpulan data, penulis menggunakan dua cara. Pertama Angket, yaitu metode pengumpulan data yang dilakukan dengan cara memberi seperangkat pertanyaan atau pernyataan tertulis kepada responden. Angket diperuntukkan bagi mahasiswa saja, karena jumlah mahasiswa yang sangat banyak yaitu mencapai lebih dari 10.000 mahasiswa. Penggunaan angket ini bertujuan untuk memetakan pengetahuan mahasiswa UIN Imam Bonjol Padang tentang kebersihan lingkungan dan pengamalan pengetahuan tersebut. Melalui angket yang disebarkan dalam jumlah yang banyak tersebut, data yang didapatkan menjadi lebih akurat.

Penentuan jumlah angket yang disebarkan kepada mahasiswa UIN Imam Bonjol Padang menggunakan teori Slovin dengan batas toleransi kesalahan 6\%. Dengan jumlah keseluruhan mahasiswa UIN Imam Bonjol Padang 10.708, jumlah angket yang harus disebarkan adalah sebanyak 271 angket dengan perbandingan yang sesuai dengan jumlah mahasiswa setiap fakultas. Data tersebut terdiri dari Fakultas Adab dan Humaniora sebanyak 26 angket, Fakultas Syari'ah sebanyak 40 angket, Fakultas Dakwah dan Ilmu Komunikasi sebanyak 39, Fakultas Ushuluddin dan Studi Agama sebanyak 26, Fakultas Ekonomi dan Bisnis Islam sebanyak 39 angket dan Fakultas Tarbiyah dan Keguruan sebanyak 101 angket. Dalam perjalanan penelitian, angket yang dikembalikan kepada peneliti sebanyak 262 angket. Kedua, peneliti menggunakan metode wawancara. Metode ini digunakan untuk mendapatkan data yang lebih rinci mengenai pemahaman dan perilaku civitas akademika UIN Imam Bonjol Padang terkait kebersihan lingkungan. Penentuan sampel untuk wawancara dilakukan dengan prosedur quota yaitu teknik sampling berdasarkan jumlah atau jatah yang telah ditentukan. Dalam hal ini, penulis mengambil sampel sebanyak 24 orang informan yang terdiri dari 6 orang dosen laki-laki dari masingmasing fakultas selingkup UIN Imam Bonjol Padang, 6 orang dosen perempuan, 6 orang mahasiswa dan 6 orang mahasiswi UIN Imam Bonjol Padang.

Penelitian ini menggunakan tiga tahap analisis data menurut Miles dan Huberman dalam (Bungin, 2007) yaitu reduksi data, penyajian data dan penarikan kesimpulan. Reduksi data merupakan proses pemilihan, pemokusan, penyederhanaan, abstraksi, dan pentransformasian "data mentah" yang ada dalam catatan lapangan, kemudian membuatkan tema-tema, pemisahan dan memo-memo berdasarkan pertanyaan penelitian. Penyajian data yaitu tahap menarasikan data-data yang telah di reduksi sebelumnya. Penyajian data akan mempermudah langkah analisis data selanjutnya. Tahap selanjutnya adalah penarikan kesimpulan. Pada tahap terakhir ini akan diketahui bagaimana pemahaman civitas akademika UIN Imam Bonjol Padang tentang kebersihan lingkungan, cara mereka menjaga kebersihan lingkungan dan hubungan antara pengetahuan tersebut dengan pengamalan di kalangan civitas akademika UIN Imam Bonjol Padang.

\section{Pemahaman Civitas Akademika Terhadap Kebersihan Lingkungan}

Secara umum, kebersihan mencakup dua hal yaitu kebersihan diri dan lingkungan. Kondisi kebersihan yang buruk tidak hanya menyebabkan masalah pada kesehatan fisik, namun juga berpengaruh terhadap psikis manusia. Lingkungan yang bersih akan terwujud dengan adanya penjagaan dan prilaku peduli lingkungan pada setiap elemen masyarakat yang tinggal di lingkungan tersebut. Di UIN Imam Bonjol Padang, civitas akademika yaitu dosen dan mahasiswa adalah komponen terbesar dalam masyarakat kampus.

Terkait pemahaman civitas akademika UIN Imam Bonjol tentang kebersihan lingkungan, terdapat tiga hal yang dapat menjadi tolok ukur pemahaman tersebut. Pertama, pengetahuan civitas akademika tentang konsep kebersihan lingkungan. Kedua, pengetahuan civitas akademika mengenai situasi kebersihan lingkungan di UIN Imam Bonjol Padang. Ketiga, pengetahuan civitas akademika terkait fakta kebersihan lingkungan di UIN Imam Bonjol Padang. Temuan di lapangan menunjukkan bahwa pemahaman civitas 
akademika UIN Imam Bonjol Padang tentang kebersihan sudah cukup baik pada tingkat pengetahuan, namun masih di arena domistik dan bersifat individu sehingga belum bersifat aplikatif untuk kebersihan lingkungan atau ruang publik lainnya. Hal ini dapat dilihat dalam diagram berikut.

Diagram 1. Aspek Terpenting dalam Kebersihan

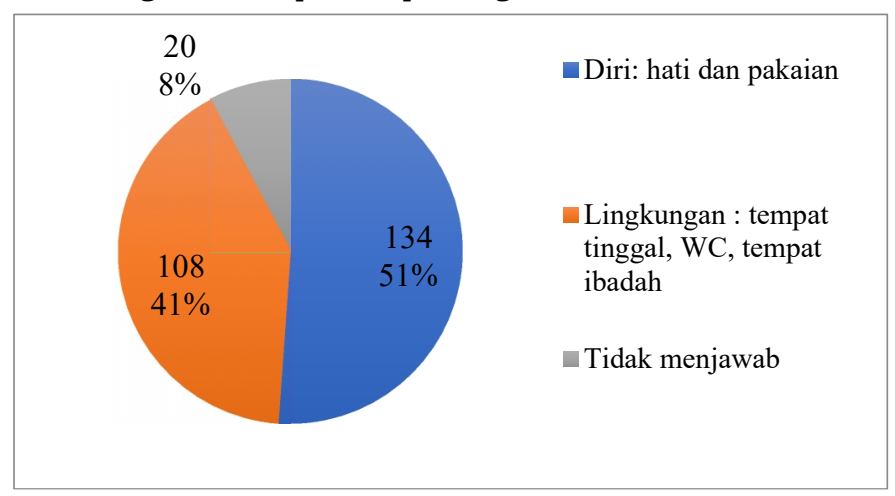

Diagram di atas menggambarkan bahwa sebanyak 134 orang atau $51 \%$ responden memilih kebersihan diri sebagai yang terpenting, $41 \%$ responden memilih kebersihan lingkungan dan 8\% lainnya tidak menjawab pertanyaan yang diajukan. Hal ini sejalan dengan pernyataan Pirgo Yuhardi bahwa kebersihan yang utama adalah kebersihan diri dan barulah kemudian kebersihan lingkungan. Pirgo menyampaikan bahwa penting untuk menjaga diri dari kotoran, baik diri secara fisik maupun psikis dengan cara memulai menumbuhkan niat dari diri sendiri untuk menjaga kebersihan. Setelah itu juga menjaga kebersihan lingkungan dengan cara membersihkannya dari sampah. Sedangkan menurut Peki, selain kebersihan diri (baik fisik maupun psikis), kebersihan juga berhubungan dengan lingkungan seperti kebersihan tempat tinggal dan lingkungan sosial. Pengetahuan tersebut terkait dengan nilai-nilai dalam Islam, khususnya hadis. Hal ini dapat diketahui setidaknya dari dua hal, yaitu apakah responden mengetahui tentang konsep kebersihan dalam Islam dan konsep yang bersumber dengan hadis. Selanjutnya dapat dilihat pada diagram di bawah ini.

Diagram 2. Pengetahuan Terhadap Konsep Islam Tentang Kebersihan

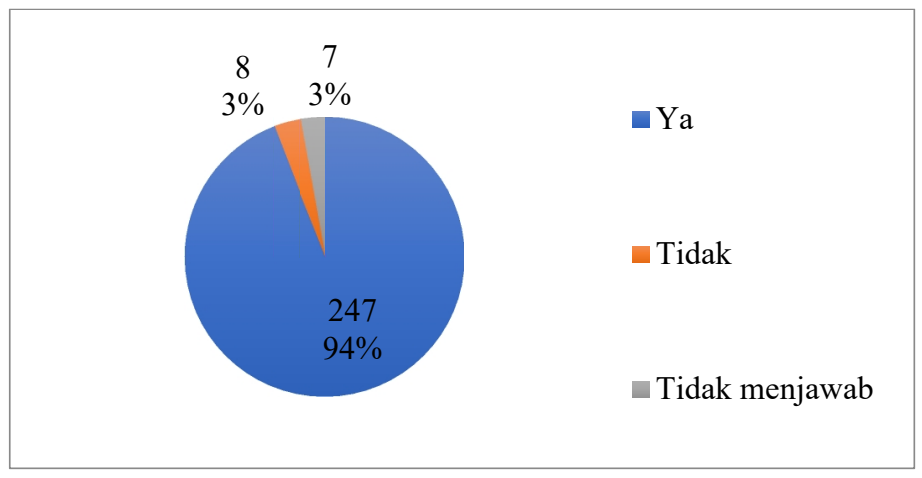

Mengenai adanya konsep kebersihan dalam Islam, mayoritas responden menjawab bahwa Islam memiliki konsep kebersihan, yaitu sebanyak 94\%, sementara 3\% lainhya menjawab bahwa Islam tidak memiliki konsep kebersihan, dan 3\% lainnya tidak menjawab pertanyaan. Hal ini bermakna bahwa civitas akademika UIN Imam Bonjol Padang mengetahui bahwa Islam mengatur hal-hal terkait kebersihan. Menurut Ahmad Busyrowi, dosen di Fakultas Adab dan Humaniora, konsep kebersihan dalam Islam yaitu:

"kita banyak mempunyai konsep, tentang kebersihan, tentang menghargai waktu, kita juga punya annazafatul minal iman, kebersihan itu sebagian dari iman, separuh dari iman". 
Menurut Busyrowi, Islam memiliki konsep tentang kebersihan yaitu "annazhafatu minal iman".

Identifikasi terhadap sumber pengetahuan tentang konsep kebersihan dalam Islam menurut civitas akademika UIN Imam Bonjol Padang dapat dilakukan dari analisis data kuantitatif berikut.

Diagram 3. Pengetahuan Terhadap Konsep Kebersihan yang Bersumber dari Hadist

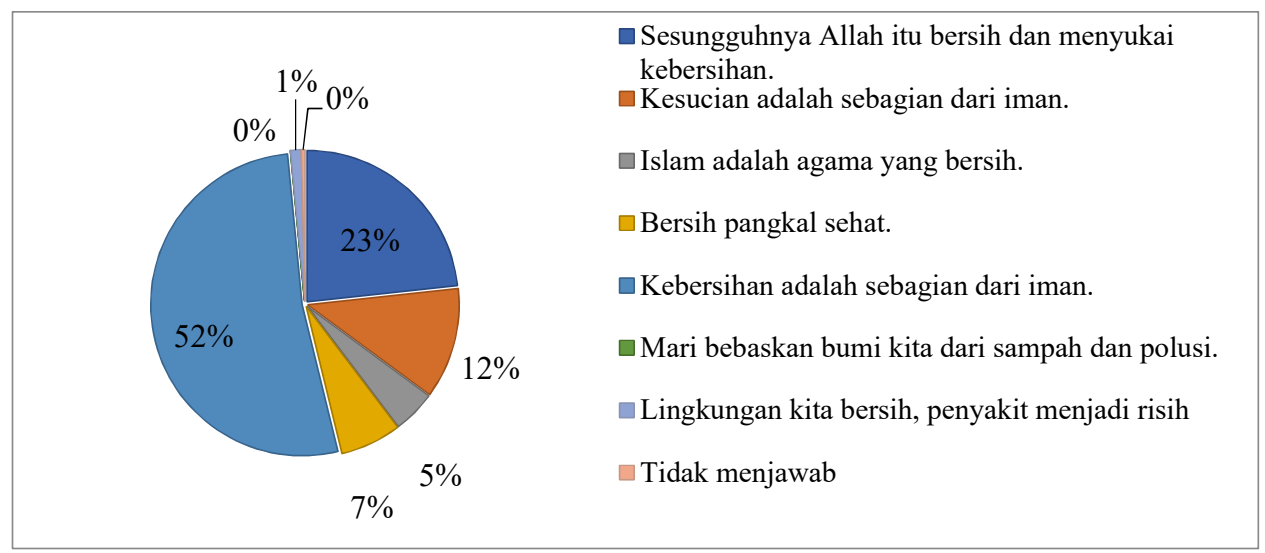

Berdasarkan diagram di atas, pengetahuan civitas akademika UIN Imam Bonjol Padang tentang hadis terkait kebersihan terbilang sangat tinggi. Hal ini dibuktikan dengan pilihan terhadap konsep-konsep kebersihan yang bersumber pada hadis mencapai $87 \%$, yaitu pilihan terhadap konsep "sesungguhnya Allah itu bersih dan menyukai kebersihan", "Kesucian adalah sebagian dari iman" dan konsep "kebersihan adalah sebagian dari iman"..

\section{Cara Menjaga Kebersihan Lingkungan Civitas Akademika}

Kebersihan merupakan suatu kondisi yang menuntut adanya penjagaan yang berkelanjutan. Kebersihan erat kaitannya dengan sarana dan prasarana penunjang kebersihan seperti air bersih dan tempat sampah. Selain itu, hal yang terpenting dalam kebersihan adalah perilaku masyarakat di lingkungan tersebut. Perilaku masyarakat yang tidak peduli terhadap kebersihan menjadi faktor utama buruknya kondisi kebersihan suatu lingkungan. Disamping dua hal diatas, regulasi terkait kabersihan juga berperan agar kebersihan di lingkungan tersebut lebih terjaga.

Diagram 4. Ketersediaan Air Bersih di UIN Imam Bonjol

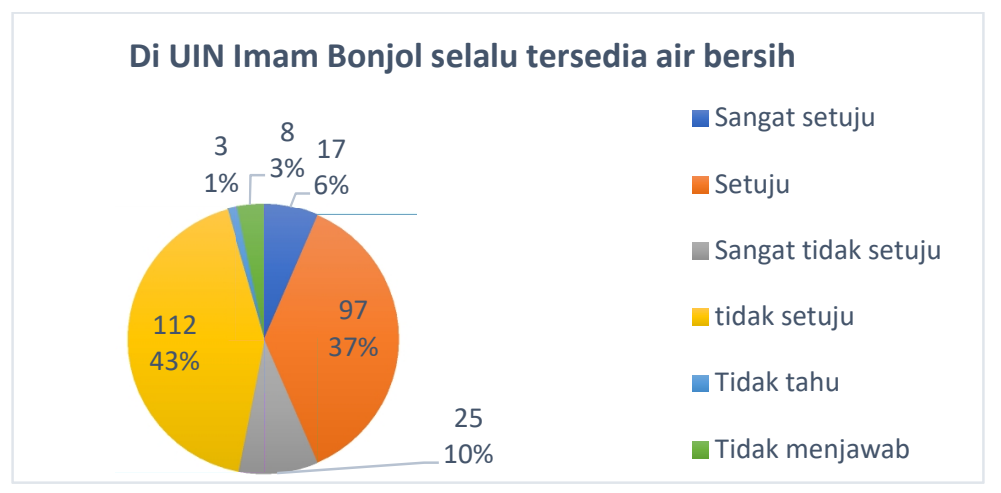

Hasil penelitian menunjukkan bahwa, pertama civitas akademika UIN Imam Bonjol sangat tergantung pada sarana dan prasarana dalam menjaga kebersihan lingkungan diantaranya air bersih dan tempat sampah. Sarana dan prasarana bersifat sangat kondisional seperti di waktu tertentu di beberapa fakultas sudah tersedia air bersih yang 
cukup, namun tidak demikian dengan fakultas lain. Kondisi ini disebabkan oleh tidak seimbangnya jumlah debit air yang disediakan dengan jumlah pemakai air bersih tersebut. Demikian pula dengan tempat sampah yang belum merata penyediaanya. Berikut diagram terkait ketersediaan air bersih di UIN Imam Bonjol Padang.

Terkait ketersediaan air bersih, 6\% responden sangat setuju bahwa di di UIN Imam Bonjol selalu tersedia air bersih, 37\% responden menyatakan setuju, 10\% menyatakan sangat tidak setuju dan $43 \%$ tidak setuju. Sementara 1\% responden menyatakan tidak tahu dan 3\% lainnya tidak menjawab pertanyaan yang diajukan. Menurut Netta, dosen Fakultas Ekonomi dan Bisnis Islam UIN Imam Bonjol Padang, berdasarkan ukurannya, air di Fakultas Ekonomi dan Bisnis Islam sudah terbilang cukup. Hanya saja ketika banyak tamu akan dijumpai kondisi air yang habis. Sedangkan menurut Khadijah, dosen Fakultas Tarbiyah dan Keguruan UIN Imam Bonjol Padang, jika dibandingkan dengan jumlah mahasiswa, air yang tersedia memang belum mencukupi kebutuhan.

Sarana kebersihan lainnya yang sangat mendukung terciptanya lingkungan yang bersih selain air bersih adalah tempat sampah. Mengenai ketersediaan sarana tersebut, 8\% responden sangat setuju bahwa di setiap taman, kantor, ruang kelas dan WC di UIN Imam Bonjol disediakan tempat sampah. Sedangkan 33\% rensponden menyatakan setuju. Sementara $12 \%$ rensponden menyatakan sangat tidak setuju, 38\% tidak setuju, 3\% tidak tahu dan $6 \%$ lainnya tidak menjawab pertanyaan yang diajukan. Data selengkapnya dapat dilihat pada diagram 5 .

Diagram 5. Tempat Sampah di UIN Imam Bonjol

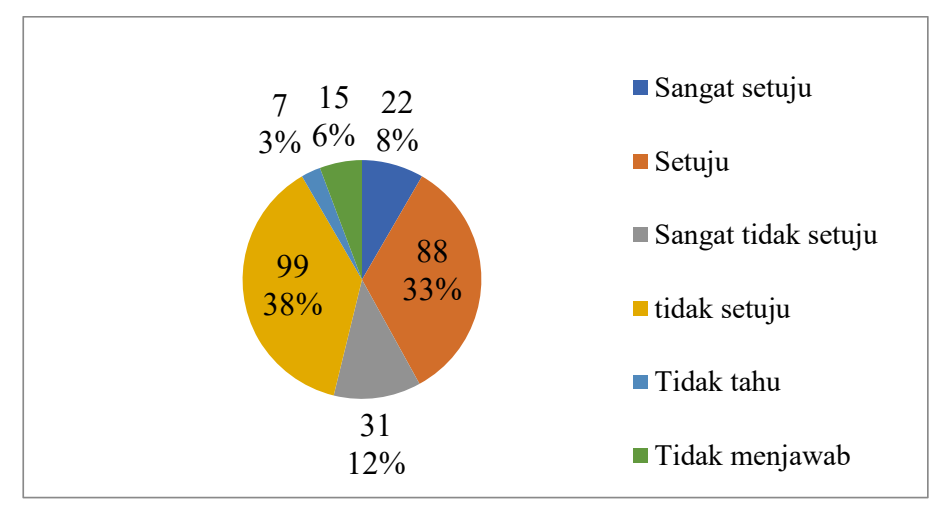

Kedua, terkait perilaku kebersihan civitas akademika UIN Imam Bonjol Padang, menurut $81 \%$ civitas akademika UIN Imam Bonjol Padang, tingkat kesadaran civitas akademika UIN Imam Bonjol Padang dalam menjaga kebersihan masih tergolong rendah. Sedangkan penilaian terhadap kepedulian terhadap kebersihan hampir berimbang, 45\% menyatakan peduli dan 43\% menyatakan bahwa civitas akademika UIN Imam Bonjol Padang belum peduli dan belum menjaga kebersihan lingkungan. Dalam perilaku membuang sampah, sebanyak 45\% rensponden menilai bahwa civitas akademika UIN Imam Bonjol Padang telah membuang sampah pada tempatnya dan $41 \%$ rensponden menilai bahwa civitas akademika UIN Imam Bonjol Padang belum membuang sampah pada tempatnya. Perilaku kebersihan ini sangat terkait dengan aspek yang ketiga, yaitu regulasi tentang kebersihan yang ada di UIN Imam Bonjol Padang.

Diagram 6 menggambarkan bahwa menurut 48\% civitas akademika di UIN Imam Bonjol Padang, tidak ada peraturan tertulis tentang kebersihan. Sedangkan 32\% rensponden lainnya berpendapat bahwa ada peraturan tertulis terkait hal tersebut. Selebihnya, $12 \%$ rensponden menjawab tidak tahu dan $8 \%$ rensponden lainnya tidak menjawab pertanyaan yang diajukan. Mengenai tindakan tegas atau sanksi bagi yang tidak menjaga kebersihan, lebih dari separuh responden atau $75 \%$ setuju bahwa di UIN Imam Bonjol Padang, tidak ada sanksi atau tindakan tegas dalam hal tersebut. Data selengkapnya dapat dilihat pada diagram di bawah ini. 
Diagram 6. Peraturan tertulis tentang Kebersihan di UIN Imam Bonjol Padang

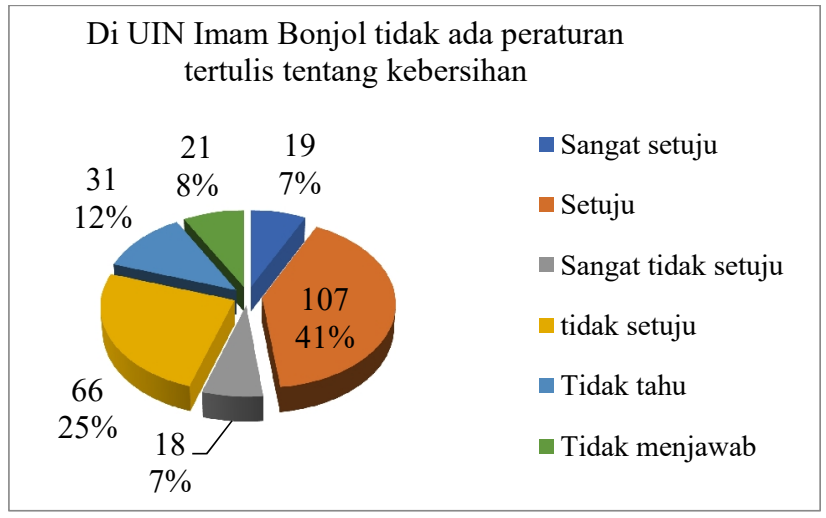

Diagram 7. Tindakan dan Sanksi bagi yang Tidak Menjaga Kebersihan di UIN Imam Bonjol

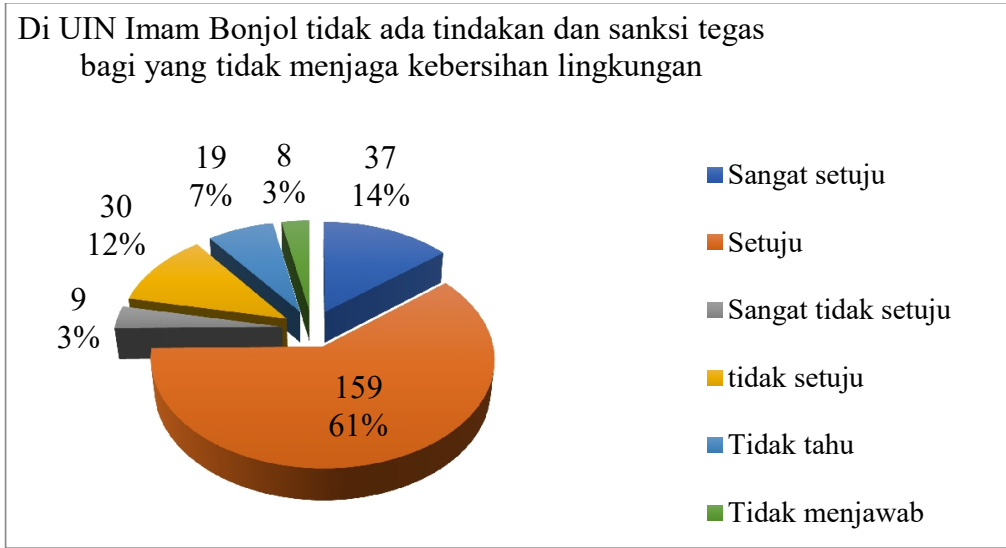

Selian itu, diagram 8 menunjukkan bahwa menurut 76\% civitas akademika UIN Imam Bonjol Padang menyatakan bahwa tidak banyak himbauan untuk menjaga kebersihan lingkungan. Sedangkan $18 \%$ rensponden lainnya tidak beranggapan demikian, 5\% rensponden menjawab tidak tahu dan $1 \%$ lainnya tidak menjawab pertanyaan yang diajukan.

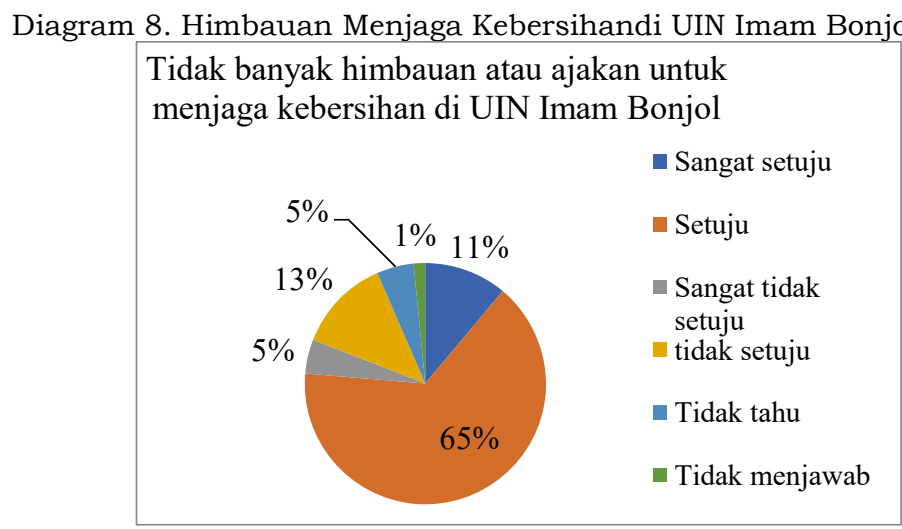

\section{Hubungan Pengetahuan dan Pengamalan Kebersihan Civitas Akademika UIN Imam Bonjol Padang}

Dalam menganalisa hubungan tentang pengetahuan dengan pengamalan, sangat terkait dengan tingkat pengetahuan dan pengamalan pengetahuan itu sendiri. Ditemukan bahwa pengetahuan tentang kebersihan lingkungan mayoritas civitas akademika UIN Imam Bonjol 
Padang sangat tinggi dan pada dasarnya bersumber pada hadis. Data selengkapnya dapat dilihat pada diagram di bawah ini.

Diagram 9. Sumber Pengetahuan tentang Kebersihan Lingkungan

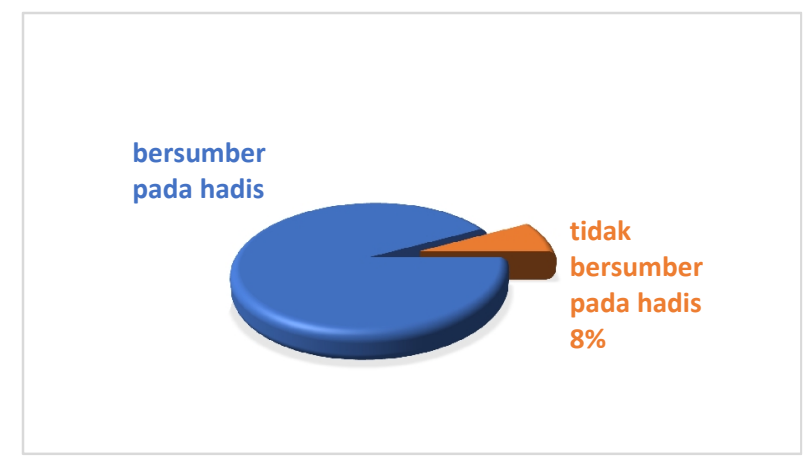

Diagram di atas menunjukkan bahwa, 92\% civitas akademika UIN Imam Bonjol Padang mempunyai pengetahuan tentang kebersihan lingkungan yang bersumber pada hadis, sedangkan $8 \%$ rensponden lainnya tidak bersumber pada hadis. Hal ini juga bermakna bahwa 92\% civitas akademika UIN Imam Bonjol Padang mengetahui hadis tentang kebersihan. Sumber pengetahuan tentang hadis tersebut juga berbeda-beda untuk setiap individu. Sumber tersebut ada yang berasal dari kitab hadis secara langsung, melalui buku-buku, ceramah agama baik langsung ataupun melalui media dan sumber-sumber lain yang dapat memberi informasi terkait hadis tentang kebersihan.

Mengenai pengamalan, peneliti menemukan hal yang sedikit berbeda dimana tingkat pengamalan pengetahuan tentang kebersihan lingkungan civitas akademika UIN Imam Bonjol Padang masih berada pada level cukup. Indikator pengamalan pengetahuan tentang kebersihan di kalangan civitas akademika UIN Imam Bonjol Padang diidentifikasi dari usaha untuk menerapkan pengetahuan tersebut melalui pembiasaan-pembiasaan perilaku peduli kebersihan lingkungan, sehingga terciptalah lingkungan yang bersih. Dengan kata lain, lingkungan yang bersih adalah cerminan dari perilaku kebersihan yang baik, juga sebagai bentuk pengamalan dari pengetahuan yang dimiliki orang-orang yang berada di lingkungan tersebut. Berikut diagram dari jawaban responden terkait kondisi kebersihan lingkungan UIN Imam Bonjol Padang.

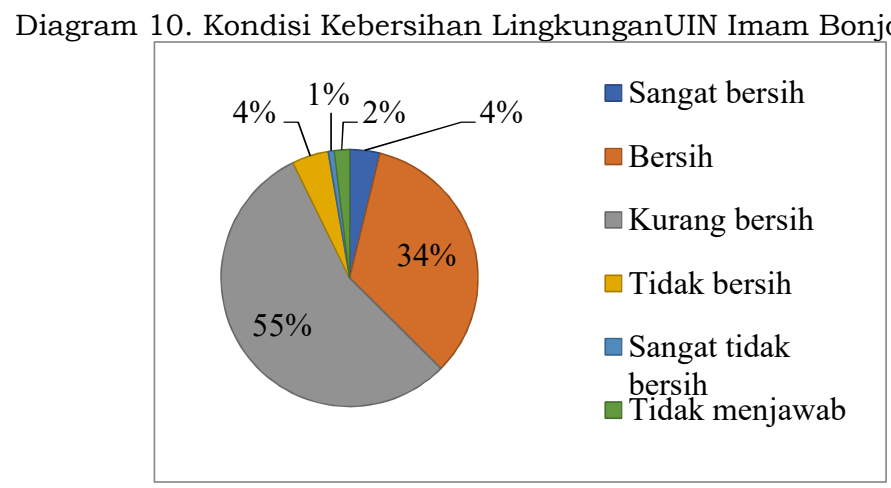

Diagram di atas menunjukkan bahwa penilaian responden terhadap kondisi kebersihan lingkungan UIN Imam Bonjol beragam, 4\% menilai lingkungan UIN Imam Bonjol sangat bersih, 34\% menilai bersih, 55\% menilai kurang bersih, 4\% menilainya tidak bersih, 1\% menilainya sangat tidak bersih dan $2 \%$ lainnya tidak menjawab pertanyaan yang diajukan. Data kualitatif untuk menunjang data-data di atas adalah hasil wawancara penulis dengan beberapa informan berikut. Huriyatul Akmal, dosen Fakultas Ekonomi dan Bisnis Islam UIN Imam Bonjol Padang, menyampaikan bahwa kondisi kebersihan kampus sudah 
termasuk baik selama ada petugas kebersihan. Hal ini mengindikasikan kepedulian civitas akademika UIN Imam Bonjol Padang terhadap kebersihan masih tergolong rendah. Kondisi bersih terwujud karena ada petugas kebersihan yang membersihkan kotoran dan sampahsampah yang ada. Jadi, jika tidak ada petugas kebersihan, kondisi kebersihan lingkungan tidak akan membaik.

Senada dengan pendapat Huriyatul Akmal, menurut Nurhayati Zain yang juga seorang dosen di Fakultas Adab dan Humaniora, kondisi kebersihan UIN Imam Bonjol Padang sudah membaik. Hanya saja dibeberapa tempat, kebersihannya belum maksimal. Hal ini disebabkan karena petugas kebersihan belum mengerti teknik penyelenggaraan kebersihan sehingga di beberapa tempat belum bersih secara maksimal. Selain itu, pemakai (civitas akademika UIN Imam Bonjol Padang) juga menjadi penyebab tidak maksimalnya kondisi kebersihan lingkungan di UIN Imam Bonjol Padang. "Pemakai" begitu Nurhayati menyebutkan, belum mengerti cara penggunaan yang baik sehingga fasilitas yang ada rentan kotor dan rusak. Sedangkan menurut Informan dari pihak mahasiswa, kondisi kebersihan UIN Imam Bonjol Padang masih terbilang belum bersih dan belum indah. Berikut pernyataan Peki terkait hal tersebut.

\begin{abstract}
"Menurut saya, belum bersih secara maksimal. Apalagi dalam konteks tersusun rapi. Seperti yang bisa kita saksikan sendiri, tidak menyenangkan memandang lingkungan UIN Imam Bonjol. Di sebelah masjid kampus, banyak pohon-pohon yang tidak rapi susunannya, banyak tumpukan batu, tidak bersih. Sehingga tidak enak dipandang."
\end{abstract}

Data-data di atas menunjukkan bahwa kondisi kebersihan UIN Imam Bonjol Padang masih belum bisa dikategorikan sebagai lingkungan yang bersih. Hal ini juga didukung dengan data terkait perilaku kebersihan di bawah ini.

Diagram 11. Perilaku Kebersihan Civitas Akademika UIN Imam Bonjol Padang

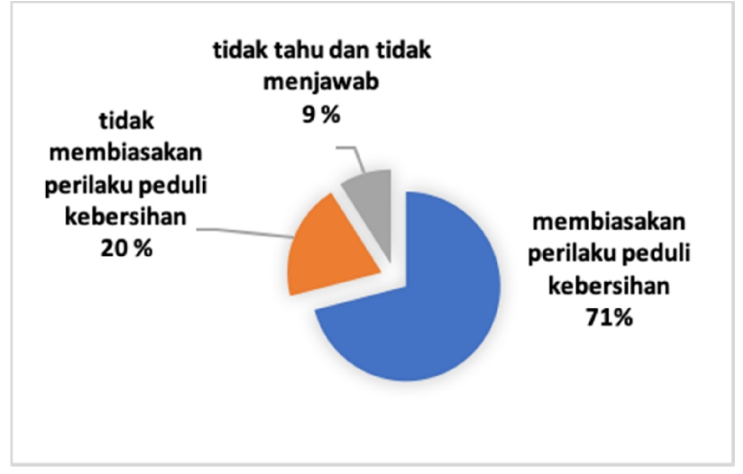

Dari diagram di atas dapat dipahami bahwa $71 \%$ civitas akademika UIN Imam Bonjol Padang mengaku sudah membiasakan perilaku peduli kebersihan lingkungan, sedangkan $20 \%$ lainnya tidak membiasakan perilaku tersebut dan 9\% lainnya tidak tahu dan tidak menjawab pertanyaan yang diajukan. Berdasarkan hal ini, terlihat pengamalan pengetahuan civitas akademika UIN Imam Bonjol Padang tentang kebersihan khususnya yang bersumber pada hadis dengan kisaran 92\% tidak berbanding lurus dengan pengamalannya, dimana terdapat kesenjangan sebanyak 21\%. Terkait hubungan pengetahuan tentang konsep kebersihan yang bersumber pada hadis dengan pengamalannya, dapat di rumuskan bahwa terdapat dua bentuk hubungan yaitu:

\title{
6.1. Hubungan Simetris
}

Hubungan ini terjadi karena tingkat pengetahuan berbanding lurus dengan pengamalan. Ada beberapa kategori hubungan simetris. Pertama, civitas akademika UIN Imam Bonjol Padang mengetahui konsep-konsep kebersihan yang bersumber pada hadis lalu mengamalkannnya dalam kehidupan sehari-hari. Berdasarkan perbandingan data mengenai pengetahuan dan pembiasaan perilaku peduli kebersihan civitas akademika UIN Imam Bonjol Padang, ditemukan bahwa sebanyak 64\% civitas akademika UIN Imam Bonjol Padang mengetahui konsep-konsep kebersihan yang bersumber pada hadis lalu 
mengamalkannnya dalam kehidupan sehari-hari. Kedua, civitas akademika UIN Imam Bonjol Padang yang tidak mengetahui konsep-konsep kebersihan yang bersumber pada hadis dan tidak pula menjaga kebersihan lingkungan. Dalam hal ini ditemukan hanya 0,38\% civitas akademika UIN Imam Bonjol Padang yang tidak mengetahui konsep-konsep kebersihan yang bersumber pada hadis dan tidak pula menjaga kebersihan lingkungan.

\subsection{Hubungan Asimetris}

Hubungan ini terjadi karena tingkat pengetahuan tidak berbanding lurus dengan pengamalan. Hubungan tersebut termasuk di dalamnya adalah civitas akademika UIN Imam Bonjol Padang yang mengetahui konsep-konsep kebersihan yang bersumber pada hadis tapi tidak mengamalkannnya dalam kehidupan sehari-hari. Berdasarkan data mengenai pengetahuan dan pembiasaan perilaku peduli kebersihan, ditemukan bahwa sebanyak 20\% civitas akademika UIN Imam Bonjol mengetahui konsep-konsep kebersihan yang bersumber pada hadis tapi tidak mengamalkannnya dalam kehidupan sehari-hari.

Bentuk hubungan lain yang juga tidak simetris adalah civitas akademika UIN Imam Bonjol Padang yang tidak mengetahui konsep-konsep kebersihan yang bersumber pada hadis, tetapi membiasakan perilaku peduli kebersihan lingkungan. Ditemukan bahwa sebanyak 7\% civitas akademika UIN Imam Bonjol Padang tidak mengetahui konsep-konsep kebersihan yang bersumber pada hadis, tetapi membiasakan perilaku peduli kebersihan lingkungan berdasarkan pengetahuannya dari sumber lain.

\section{Kesimpulan}

Berdasarkan hasil penelitian ini, dapat disimpulkan beberapa hal. Pertama, pemahaman civitas akademika UIN Imam Bonjol Padang tentang kebersihan sudah cukup baik pada tingkat pengetahuan namun masih bersifat privat atau individu, belum masuk ke wilayah publik atau lingkungan. Pemahaman tersebut pada dasarnya bersumber pada ajaran agama salah satunya hadis tentang kebersihan, baik secara lafaz maupun secara substansi. Kedua, terdapat tiga hal yang berhubungan dengan cara civitas akademika UIN Imam Bonjol Padang menjaga kebersihan lingkungan, yaitu terkait sarana dan prasarana kebersihan, perilaku kebersihan dan regulasi tentang kebersihan. Ketiganya hal ini saling berhubungan dimana perilaku kebersihan civitas akademika UIN Imam Bonjol Padang dipengaruhi oleh kurang tersedianya sarana dan prasarana kebersihan dan tidak adanya regulasi terkait hal tersebut. Ketiga, ada dua bentuk hubungan pengetahuan tentang kebersihan dan pengamalan di kalangan civitas akademika UIN Imam Bonjol Padang. Pertama, hubungan simetris dimana 64\% civitas akademika UIN Imam Bonjol Padang mengetahui konsep kebersihan yang bersumber pada hadis dan mengamalkannya, $0,38 \%$ civitas akademika UIN Imam Bonjol Padang tidak mengetahui konsep kebersihan yang bersumber pada hadis dan tidak pula menjaga kebersihan lingkungan. Kedua, hubungan yang tidak simetris dimana 20\% civitas akademika UIN Imam Bonjol Padang mengetahui konsep kebersihan yang bersumber pada hadis namun tidak mengamalkannya, dan $7 \%$ civitas akademika UIN Imam Bonjol Padang yang tidak mengetahui konsep kebersihan yang bersumber pada hadis tetapi menjaga kebersihan berdasarkan pengetahuannya dari sumber lain. Pengetahuan civitas akademika UIN Imam Bonjol Padang tentang kebersihan lingkungan tidak berbanding lurus dengan pengamalannya; pengetahuan civitas akademika UIN Imam Bonjol Padang tentang kebersihan lingkungan sudah berada pada level sangat tinggi sekali, sedangkan pengamalannya masih berada pada level cukup. Hal ini disebabkan oleh pemahaman civitas akademika UIN Imam Bonjol Padang tentang kebersihan lingkungan masih di area domestik dan bersifat privat, belum masuk ke ruang publik.

\section{Daftar Pustaka}

Abdullah, I. (2006). Konstruksi dan Reproduksi Kebudayaan (1st ed.). Yogyakarta: Pustaka Pelajar.

Agus, B. (2006). Agama Dalam Kehidupan Manusia: Pengantar Antropologi Agama. Jakarta: PT Raja Grafindo Persada. 
Arditi, B. (2004). Populism as a Spectre of Democracy: A Response to Canovan. Political Studies, 52(1), 135-143. https://doi.org/10.1111/j.1467-9248.2004.00468.x

Azwar, W., \& Muliono, M. (2019). Filsafat Ilmu Pengetahuan, Cara Mudah Memahami Filsafat Ilmu Pengetahuan. Jakarta: Prenada Media Group.

Bungin, B. (2007). Penelitian Kualitatif. Jakarta: Kencana Prenada Media Group.

Efendy, I. (2018). Konstruksi Pendidikan Kesehatan Lingkungan Dalam Perspektif Islam. MIQOT: Jurnal Ilmu-Ilmu Keislaman, 40(2). https://doi.org/10.30821/miqot.v40i2.305

Farmer, M. A., Trapnell, P. D., \& Meston, C. M. (2009). The Relation Between Sexual Behavior and Religiosity Subtypes: A Test of the Secularization Hypothesis. Archives of Sexual Behavior, 38(5), 852-865. https://doi.org/10.1007/s 10508-008-9407-0

Firdaus, F. (2012). Puar Cama Untuk Anak Cucu: Kearifan Lokal Untuk Sustainability Forest di Manggarai Barat. Jurnal Ilmu Sosial Mamangan, 1(1), 39-50.

Kahmad, D. (2009). Sosiologi Agama. Bandung: PT Remaja Rosdakarya.

Maliki, Z. (2011). Agama dan Lingkungan Hidup, 14(1), 137-147.

Nora, L., \& Minarti, N. S. (2016). The Role of Religiosity, Lifestyle, Attitude As Determinant Purchase Intention. In The 2nd International Multidisciplinary Conference 2016 (pp. 135-148). Universitas Muhammadiyah Jakarta.

Ritzer, G., \& Goodman, D. J. (2010). Teori Sosiologi: Dari Teori Klasik Sampai Perkembangan Mutakhir Teori Sosial Posmodern. Yogyakarta: Kreasi Wacana.

Swim, J. K., Stern, P. C., Doherty, T. J., Clayton, S., Reser, J. P., Weber, E. U., ... Howard, G. S. (2011). Psychology's Contributions to Understanding and Addressing Global Climate Change. American Psychologist, 66(4), 241-250. https://doi.org/10.1037/a0023220

Syahputra, I. (2016). Agama di Era Media: Kode Religius dalam Industri Televisi Indonesia. Esensia, 1(17), 125-138. 